\title{
Social and cultural activity of Ukrainian progressive intellectuals of the late 19th - early 20th centuries
}

\author{
Oksana Kravchenko ${ }^{1, *}$ and Iryna Albul ${ }^{2, * *}$ \\ ${ }^{1}$ Pavlo Tychyna Uman State Pedagogical University, 2 Sadova Str., Uman, 20300, Ukraine
}

\begin{abstract}
The article deals with the social and cultural activities of Volodymyr Naumenko (1852-1919), a prominent representative of the Ukrainian progressive intellectuals of the late 19th - early 20th centuries, teacher and methodologist, editor and publisher, scholar and politician, educator and active public figure. Some aspects of V. Naumenko's creative activity aimed at reviving the national consciousness of the Ukrainian people through the construction of an educational system on a democratic, national basis, the preparation and publishing of textbooks in the native language, the training of teaching staff for public schools are highlighted. The results of the active participation of a figure in such educational societies of the specified period as "Hromada", "Prosvita", "Society for promotion of primary education", "Kyiv Literacy Society" are presented. V. Naumenko's views on the process and features of teacher training for public schools are characterized.
\end{abstract}

\section{Introduction}

At the present stage of cultural and historical development of Ukraine, it is crucial for public attention to be focused on the society as a stable social community, characterized by the unity of living conditions and community of culture. To characterize a particular social and cultural situation of personality development, several factors must be considered, namely: factors of internal development (economic model of development, social dynamics, changes occurring in the state system and political regime), historical factors (national cultural development, spirit of upbringing of generations), influence of the world social and cultural situation.

The concept of social and cultural activity has two aspects - cultural and social, and determines the content of the two concepts: "cultural activity" and "social work". The object of social and cultural activity is sociopedagogical and socio-cultural environment of human existence. The subject of social and cultural activity are any possible means and forms of active influence of sociopedagogical and socio-cultural environment on the spiritual development of different social, age, professional and ethnic groups, their education and upbringing.

The most complete and representative study of the educational and upbringing phenomena of the past is possible only in the context of the development of national pedagogical thought. The study and analysis of personalities as a separate subject of historical and pedagogical research is important, since personal biography is often the basis of scientific reconstruction of the era and the coverage of the pedagogical experience of a certain period.

\footnotetext{
*e-mail: okskravchenko@ukr.net

**e-mail: albuliv1977@gmail.com
}

Therefore, the priority is to revive the names of prominent cultural and educational representatives whose heritage has been removed from the historical and pedagogical process. These are the figures of the second half of the nineteenth century-beginning of the twentieth century - the period of formation of the national system of education and upbringing, the introduction of the national component in the structure of pedagogical science, the epoch of the birth of a whole galaxy of famous and significant educators, representatives of education and art. First of all, they are the members of "Hromada" and other educational organizations whose purpose was to spread education among people, to form a national idea and national mentality, to develop and preserve Ukrainian culture. The main directions of their pedagogical and cultural studies were collecting, highlighting and revealing sources of folk pedagogy, exploring the cultural heritage of the past.

\section{Materials and methods}

The activities of the Ukrainian intelligentsia took place under the influence of liberation ideas, which were established in the Ukrainian lands in the second half of the 19 th century - in the early 20th century, and were associated with the national education movement and the development of Ukrainian nation-building. Among the scholars in the field of history of Pedagogy, the sociocultural activity of the Ukrainian intelligentsia was studied by L. Berezivska [1], L. Vovk [2], I. Zaichenko [3], I. Likarchuk [4, 5], N. Pobirchenko [6], I. Nadiezhdina [7].

The objective of this study is to highlight and analyze the main areas of cultural and educational activities of Volodymyr Naumenko as a representative of the Ukrainian 
progressive intelligentsia of the late 19th - early 20th century and to determine the role of the figure in the formation of Ukrainian education.

The methodological basis of the study are the main provisions of the theory of scientific knowledge: the unity of historical and logical; the importance of subjective experience as the main measure of the essence of human personality; consideration of the phenomena and facts of creative life of the teacher through historical and cultural principles; determining the role of an active person in the history of education, pedagogical science.

The research was carried out on the basis of the historical approach, using the comparative-historical method, which allowed to investigate the emergence, formation and development of processes and events in chronological sequence in order to identify internal and external connections, patterns and contradictions.

Thanks to the system-activity approach the component structure of human activity was studied: need - subject - object - processes - conditions - result, and personal activity was considered as a dynamic system of human interaction with the external environment, as well as a specific professional, scientific, educational, etc. form of human activity, in which one reaches certain heights through the use of socio-cultural approach in the process of research, the attention was focused on the strategic social goals of historical reproduction of society with its national cultural specifics and systemic characteristics of culturalvalue complexes of social adequacy and cultural competence of new members of this society. Its use has provided a multi-factorial approach to the study of socio-cultural environment (space), the mechanisms of communication of "social" and "cultural" systems.

\section{Results and discussion}

Volodymyr Naumenko (1852-1919) - a teacher and methodologist, editor and publisher, scientist and politician, educator and active public figure had a worthy place among those who worked on the development of national pedagogical thought, education in native language and presented Ukrainian pedagogy as an integral part of national culture.

V. Naumenko left a significant pedagogical legacy textbooks, manuals, programs, publications in periodicals, methodical developments, valuable manuscripts, epistolary. His works have not only pedagogical, but also universal historical value, because they reflect the actual problems of the development of Ukrainian state, cultural, political and spiritual development of the Ukrainian people in the second half of the 19th century - in the early 20th century.

Representatives of the social and educational movement saw the way to preserving the nation precisely in the development of the school, in the enlightenment of the people, in the creation of the national system of education. This case was quite complicated because everything Ukrainian was strictly forbidden in Ukrainian: language, history, literature, culture. For Ukrainian children the educational process was held in a foreign language. The task of the social and educational movement was not only to teach the mass literacy and provide the necessary knowledge that would be sufficient for certain life needs, but also to open up the world to a person, to elevate his role in public life, to show the connection with the environment, to give it an opportunity to get acquainted with national history, to study the lives of their predecessors and to reflect on the present.

In order to revive the national consciousness of the Ukrainian people, Volodymyr Naumenko considered it necessary to build an educational system on a democratic, national basis, to conclude and publish textbooks in the native language, to train teaching staff for public schools. He understood that in order to create a nationally conscious generation of Ukrainians, it was necessary to reform the education system of that time, and he considered the main task to be the introduction of education in native language, especially in the initial period of study. V. Naumenko, as a teacher-practitioner, argued that a primary school teacher should approach the local folk dialect in his speech, using those words and expressions that are understood by the children of the area, and only gradually introduce them into the world of literary speech [8].

While giving priority to the native language of the students, V. Naumenko was convinced that in a country such as Russia, teaching should be based on the principle of nature in relation to the native language of each nationality, and even more so in elementary education. However, the scientist did not deny that the state language should take its proper place, without displacing the native language of the students.

In his article "Mother tongue as a subject of high school course" (1881) V. Naumenko considered the importance and role of the mother tongue in the secondary school course. He noted that mother tongue is, first and foremost, a means of expressing one's thoughts, and on the other hand, of knowing one's self. The author introduced the reader to the circle of folk philosophy, which is expressed in the form of words and in the combination of words. He emphasized that both folk literature and grammar of language are familiar with the people's outlook, because a certain syntactic construction of language, or another etymological form, even a phonetic feature, testify both to the nature of folk thinking, and to the level of development of the nation, its identity [9].

V. Naumenko's study “Bookish Way of Speaking of Little Ukrainians and Russinians" (1899) is also devoted to the issue of the Ukrainian language, which “... has long been a constituent of many disputes and, unfortunately, of misunderstandings" [10]. In this research the author makes some critical remarks about the individual works of Slavic scientist T. Florynskyi, who opposed the fullness of the Ukrainian language and literature. In the mentioned article Volodymyr Pavlovych emphasizes that the development of an independent original cultural language will contribute to the development of the nation. "Perhaps, the author writes, - in this latter case, the power of the people is genius, and the power of poetic sense and even the most ethical beginnings of humanity will receive greater intensity in their perfection" [10]. 
In the publication "Boosters of the Russian language in Halitsia" (1899) V. Naumenko argues that "... the complete alienation of the literary language from the vernacular is a brake on the development of the nation" [11]. However, as noted, the teacher did not deny the benefits of learning Russian literary language, as well as the benefits of knowing as many languages as possible.

V. Naumenko genuinely believed in the possibility and necessity of the existence of Ukrainian culture, education, language as well as the ability of the nation's genius to travel the difficult path to national self-awareness and self-affirmation. "If it were not for the artificial, political inoculation of Russification by any means, then the Ukrainian people would naturally go the direct way of a self-sufficient nation", V. Naumenko emphasized. He asserted that “... the government's efforts to erase the national spirit of Ukrainians for many years, trying to replace them with a Russian-language principle, have led to the domination of these Russification principles in wide circles of society. As a result, it turned out that the Ukrainian national idea met with strong resistance..." [12].

According to V. Naumenko, the development of the national school as one aspect of Ukrainian education and culture in general was closely connected with the development of the nation.

Understanding the need for nationalization of education, representatives of the Ukrainian progressive intellectuals struggled for the national school, using various forms of educational activities. In $1881 \mathrm{~V}$. Naumenko was the only teacher of Kyiv Secondary School among other teachers in Kyiv, who expressed a desire to arrange public readings in order to facilitate promotion of public education.

As a full member of the Kyiv Society for Promotion of Primary Education, V. Naumenko worked in the "Public Reading Commission", in the historical and literary section. In the list of lectures planned by the Kyiv Society for Promotion of Primary Education for 1903, among others, there were also lectures by V. Naumenko: "What was Written about the Ordinary Little Russian People 100 Years Ago", The First Printed Works of Little Russian Literacy a Hundred Years Ago (I.P. Kotliarevskyi)", "KvitkaOsnovianenko's Little Russian Short Novels" [13].

V. Naumenko's report "Taras Shevchenko and the Motives of his Poetry" opened a literary and musical evening, organized by the Kyiv Society for Promotion of Primary Education. In introducing to the people, the work of Ukrainian writers, V. Naumenko hoped to feel “... that Ukrainian movement, which by its very fact will support the strength of the Ukrainian word in our side, and at the same time will help to bring to find out our local forces" [14]. The activity of V. Naumenko in the Kyiv Society for Promotion of Primary Education was also directed at the development of Ukrainian education [15].

In 1882 the Progressive Intellectuals of Kyiv founded the Kyiv Literacy Society (1882-1908), which launched educational work in Kyiv, Podillia and Volyn provinces. The first chairman of the organization was Kyiv governor S. Hudym-Levkovich, and V. Naumenko since March 21, 1897 [1].
The Society regulations provided for: material support for existing and opening of new public schools; creating classes for adults; rewarding teachers and providing financial aid to poor students, awarding prizes for the best work aimed at educating people; publishing of books and textbooks for public reading; distribution of books and periodicals for public reading; establishment of bookwarehouses at schools; mediation in providing schools with books; formation of rural libraries.

The real purpose of the Kyiv Literacy Society according to V. Naumenko was "to serve the public education in the Southwestern Region". One of the goals of this activity was "... the creation and support of public libraries, which were opened by the Society as far as possible in all three provinces of the Southwestern Region" [16].

The Library Commission of the Kyiv Literacy Society began considerable work in creating school libraries and providing books to the public. One of the objectives of the library commission was "... free distribution of books to rural schools, rural libraries and other institutions and individuals" [17]. Its members collected information about those villages where there was a possibility to found a library, searched for a room for it, “... then, with all the necessary documents, sent the library's charter for approval to the Governor" [16]. Difficulties arose from providing libraries with literature due to a catastrophic lack of funds. And still, V. Naumenko made every effort to get his books to the rural libraries in time.

Such libraries were created not only in rural areas but also in cities. Thus, the library-reading room was also opened in Kyiv in 1899 with the purpose of "... providing to all residents of the city free use of books and periodicals for reading at home, as well as in the reading room" [17].

As a result of this activity, as noted by V. Naumenko in one of the official reports, Kyiv Literacy Society has formed more than a thousand different libraries, both on personal initiative and on behalf of various institutions. Public libraries were in high demand among the population. Thus, in 1897 the average daily visits to the 1 st Kyiv library-reading room were 36.4 , in 1898 - 38.4, in 1899 45.3 , in $1900-69.3$, in $1901-140.5$ [18].

During the work of the Library Commission under the leadership of V. Naumenko many bookstores were founded, where Ukrainian books were sold. Such bookstores were opened in Kyiv, Volyn and Podillia provinces "... to promote the distribution of the finest works of fiction and popular science literature available to people both in terms of content and price" [17].

The development of the bookstore networks for people was very important for V. Naumenko. He believed that it could significantly influence the increase of the cultural and educational level of the Ukrainian people. Such activity was not acceptable for the tsarist policy, the authorities closely followed the society and its members. Officials tried in every possible way to suppress the activities of V. Naumenko and the Kyiv Literacy Society headed by him. Thus, in one of his official addresses, the GovernorGeneral noted that the society “... recently began to provide them (libraries-reading rooms) with various kinds of brochures ... designed primarily to incite the rural popula- 
tion against the existing management order" [16]. Besides, the acquisition of libraries of educational institutions was regulated by the state documents [19].

V. Naumenko had to find arguments to defend the educational activities of Kyiv Literacy Society. Responding to allegations of misappropriation of books in the school libraries, he explained that all acquisitions were made according to the rules and regulations of state documents. The existence of "doubtful" books from the perspective of book managers explains the government's abolition of restrictions on providing libraries with books only through special catalogs. "The members of the Literacy Society sought to enrich the holdings of public libraries in the least possible way," said V. Naumenko, "of course, they took advantage of the new rules that made it possible to more fully satisfy new libraries with all those books that most satisfied the educational aspirations of the people" [16]. He insisted that, taking into account the new laws, there should be no restrictions on the acquisition of publicly accessible books by libraries. V. Naumenko also stressed that the law does not oblige a society to submit for approval lists of books that will make up the library's fund.

V. Naumenko was most criticized for the books on social sciences and national studies in the national libraries, as well as books written in Ukrainian.

The struggle was difficult. Libraries and book stores were closed, books were removed and bans were placed. However, thanks to the selfless work of V. Naumenko, the educational activity of the company did not stop. Only in 1901 did the members of the society manage to open and staff 5 public libraries, and preparations were made for the opening of such libraries in three more villages of Podillia and Volyn provinces. The report on the activities of Kyiv Literacy Society (1902) stated that the most important achievement should be considered the arrangement of public libraries within the Kyiv, Volyn and Podillia provinces [18].

Kyiv Literacy Society has also started a significant work within the framework of the school commission, which permanent member was V. Naumenko. The purpose of the school board activities was “... to develop, both theoretically and practically, all the issues related to the school business". Such a goal was specified in the following tasks: opening of new public schools; establishment of classes for lessons with adults at public schools; consideration of requests from different persons and institutions for financial support and various instructions and advice on school matters; acquaintance with life and activities of provincial schools according to the provided the reports; support of schools, founded by the society [17].

Thus, in 1900, Kyiv Literacy Society, headed by V. Naumenko, founded five schools: two for male, two for female and one with two classes, both male and female. In four of these schools, classes were held on Sunday, and in one, namely a prison school for women - on weekdays. In 1900, 750 pupils attended these schools: 518 male and 232 female. It should be noted that all the necessary educational supplies, such as books, exercise books, pencils, pens, were provided to students free of charge [18].
Opening of the Community Hall in Kyiv was one of the important forms of educational activity improvement, as well as an important condition for the unification of disparate educational institutions.

The expediency of its construction, which began in 1899, was defined by V. Naumenko as follows: "Taking the initiative to build such a house, the Literacy Society was guided, on the one hand, by the awareness of the immense benefit of such educational institutions to the people, and on the other by a deep conviction in the urgent need to build a Community Hall in Kyiv, where so little has been done for its many thousands of working-age adults" [18]. According to the report of the Society, signed by the Council Chair V. Naumenko, it is known that upon completion of the Community Hall construction it was planned to accommodate the following premises there: a large auditorium for 1000 people for reading and theatrical performances; two large halls of the free library-reading room; two halls for the mobile museum of textbooks; two halls for Sunday school and evening classes for adults; a tea room and a cheap canteen; premises for the Literacy Society bookstore; apartments for the head of the Community Hall, librarian and employees; two three-rooms apartments for rent. The purpose of this structure was to serve the public education.

V. Naumenko has been the Council Chair of Kyiv Literacy Society for 11 years. All this time he made considerable efforts to preserve the society and has contributed to his active work.

The year 1905 was quite difficult for the society because of its revolutionary sentiments. Even before the known events, the activities of the society were recognized by the official government as harmful to the masses, the more so it became noticeable at that time. V. Naumenko was forced to write an internal report addressed to the Governor-General of Kyiv, Podillia and Volyn, stating that recently, under the influence of complex relations between political parties and groups, the activities of some societies and institutions, including Kyiv Literacy Society, was criticized in media. In his report V. Naumenko argued that the main idea of Kyiv Literacy Society has always been the education of people without going through politics. Such apolitical direction was commented on by the main provisions of the Society Charter: "... to work in the spirit of the progressive and educational direction, without going beyond the limits of law" [16]. However, despite all the explanations and attempts of V. Naumenko to preserve this educational organization, the activity of the society in 1908 was stopped.

It is difficult to overestimate the importance of Kyiv Literacy Society in the education of Ukrainian people. The members of this educational organization were able to achieve significant results, which, in particular, were noted in one of the latest reports: “... a number of libraries were organized, books were collected and sent to them, mass of folk literature was organized, a warehouse was organized, a museum was founded, Sunday Schools are successfully functioning.... [18].

The merits of V. Naumenko as a leader of the society, an active figure in public education were highly ap- 
preciated by his contemporaries. At the Society's Annual Meeting in 1900 his colleagues expressed “... their gratitude especially to the Honorable Chairman of the Society V. Naumenko ... thanks to whom the Society so successfully manages .. to come off victorious from many life troubles" [18].

During his activities at Kyiv Literacy Society, V. Naumenko did not stop his active work in Kyiv community, which at the end of the 19th century has become a powerful force in a democratic society. Among the senior representatives of Kyiv community were M. Drahomanov, V. Berenshtam, P. Zhitetskyi, P. Kosach and others. V. Naumenko among others belonged to the young generation. However, the youth was not passive and did not stand aside, the young community members were concerned with the problems of Ukrainian culture and education, and worked diligently for the benefit of the nation.

Representatives of different generations of the Community were united in joint work, in particular, the creation of the Ukrainian dictionary. For this work the community members met in their own houses. Such meetings were held also at V. Naumenko's house. For many years the community members have been collecting material for this dictionary. This was of great importance for the development of Ukrainian literary language. In the early 90's, when enough material had already been collected and processed, they decided to start printing. This case was entrusted to V. Naumenko personally. He spent a lot of time for publishing the dictionary: he personally edited the first letters, sent the corrections of the dictionary, negotiated with representatives of the typography, consulted with scientists, including O. Shakhmatov.

Much work has been done to overcome the censorship bans on typing the Ukrainian dictionary. Volodymyr Pavlovych's diplomatic abilities allowed him to obtain permission to print with the condition to call the dictionary "Russian - Little Russian". Not all users of the famous "Grinchenko's Dictionary" today are aware of the dramatic events that remain only in the memoirs of contemporaries associated with the preparation of this unique edition. In light of this, we also see Volodymyr Naumenko as an amazing man, a patriot who is capable not only of dedication but also of sacrifice.

The materials for the dictionary were already on the desktop. V. Naumenko obtained the permission for printing and prepared the first part - two letters, ending with the word "borozna (furrow)". This publication has already reached the readers of the magazine "Kievskaya Starina", when it became known that the Dictionary has a chance to win an academic prize of M. Kostomarov. It was necessary to urgently revise the edition. Being busy with a magazine, public and pedagogical activities, V. Naumenko could not devote much time to work on the Dictionary.

The Dictionary Commission, consisting of E. Chykalenko, V. Berenshtam, and E. Trygubov, offered to invite B. Grinchenko to work on the edition. It was decided to pay him 100 rubles a month. Negotiations with a well-known writer took quite a long time. The point was that B. Grinchenko wanted a monopoly right in the preparation of the publication. He insisted that he himself edit all the letters and will be the only author of the publication. Such a situation was considered unjust by the community members - they insisted that the name of V. Naumenko, who gave so much energy to this case, should also be given on the cover of the Dictionary. "We wanted, - E. Chykalenko wrote, - to have the name of Naumenko on the dictionary, because he put a lot of work on it, and justice demanded moral payment for that worthless work for many years" [20].

When Volodymyr Pavlovych learned of the details of the negotiations with B. Grinchenko, he immediately relinquished his copyright to the Dictionary. He even prepared a new version of the contract himself. Moreover, he continued to work with B. Grinchenko, greatly assisting in the preparation of the publication.

In 1904, the anniversary of the Ukrainian writer Ivan Nechui-Levytskyi was celebrated in Kyiv. The Ukrainian intellectuals, who gathered at the event, approved a request to the government to improve the status of Ukrainian literature. The delegation consisting of Olena Pchilka-Kosach, Mykola Dmytriev, Volodymyr Naumenko and Illia Shrag was selected by the participants of the commemoration. The delegation went to St. Petersburg, with the appeal to the Prime Minister S. Witte, demanding to cancel restriction of the Ukrainian word. According to the member of the delegation, Olena Pchilka, V. Naumenko started talking about the state of Ukrainian life and Ukrainian word. The importance of the work of this delegation was emphasized by S. Siropolko: "Various Ukrainian organizations followed this initiative, wrote petitions about the needs of the Ukrainian school and Ukrainian word" [21].

In the history of Ukraine, the "Prosvita" Society, which operated on ethnic Ukrainian lands from 1868 to 1939, have successfully fulfilled the vital tasks of establishing a system of public education. The researcher L. Berezivska defines the type of these public organizations as "... scientific and educational, which aimed to promote the development of certain types of education or public education in general" [1].

The "Prosvita" Charter stated: "The Society aims to promote the development of Ukrainian culture and, above all, to enlighten the Ukrainian people in their native language, acting within the limits of the city of Kyiv and Kyiv province" [22]. B. Grinchenko, S. Tymoshenko, Lesia Ukrainka, V. Vinnychenko, D. Doroshenko, S. Yefremov, V. Durdukivskyi, L. Yanovska, S. Rusova, I. Ogienko and others worked in this organization. Volodymyr Naumenko was a full member of the society.

However, the activities of the society were characterized negatively by the official authorities, since, in their opinion, the said society, along with other activities, was also engaged in the production of publications, “... the purpose of which is to discredit monarchical power and to propagate republican ideas" [23]. Appreciating the "Prosvita" activities as a threat to public order, on April 8, 1910, the representatives of the tsarist authorities in Kyiv found it necessary to close this society. These events also affected V. Naumenko's career. In 1911, a secret adviser, R. Zilov, did not support V. Naumenko's request for his further work as a teacher [24]. 
1917 was a year of great change. With the victory of the February Revolution, which liquidated the autocracy, greater opportunities for the Ukrainian national education movement opened up, and a new period in the activities of educational societies began. The main organizational form of the movement for national revival of education became the Prosvita Societies, which in spring of 1917 resumed its activities. Kyiv Prosvita was one of the first in Ukraine to resume its activity. V. Naumenko was elected the Community Chair. He also chaired the general meeting on May 14, 1917 , at which the plan of work of the commissions was approved.

In the first year of existence of the Ukrainian People's Republic, the educational movement unfolded quite widely. Both in the cities and in the villages there were mentioned public organizations, which were subordinated to Kyiv Prosvita Society. The purpose of these associations was to educate their members “... in the light of good science and through the knowledge to lead them to a better public national life" [1].

In order to obtain details of all existing Prosvita Societies in Ukraine and their integration, the Extracurricular Education Department has set up an organizing committee to organize the Prosvita Congress. According to the director of the Department S. Rusova, such an idea was caused by the fact that "... there was a feeling of dissatisfaction with the Prosvita's work: there was no certain leading opinion in their activity; a central body that could provide the desired direction to the Prosvita competitions could widely provide material and moral assistance to these truly national organizations" [25].

The All-Ukrainian Prosvita Congress began its work on September 20, 1917. The opening speech was made by I. Steshenko, Secretary General of Education. V. Naumenko reported on the difficult situation of Ukrainian national education.

At this time, the issue of nationalization of education and the creation of a Ukrainian school are being actualized in the political and educational arenas. In his article "School Nationalization in Ukraine" V. Naumenko mentioned the following priorities as the most important:

- recognition of the right for the Ukrainian language to be an honorable place in schools, it should not be harassed, contemptuous or even unwanted;

- recognition the Ukrainian language as the language of teaching at primary school, and at secondary, higher and special-teaching schools as the language to be studied, with the latter being compulsory, and for the first two optional [26].

From the first days of creation of the Ukrainian People's Republic, extensive work has begun in the direction of Ukrainization of education. V. Naumenko himself reduced the problem of Ukrainization of education to two aspects: introduction of teaching in the Ukrainian language and introduction into the curriculum only some Ukrainian subjects at secondary school. The teacher emphasized that issue of teaching in Ukrainian requires consideration of the following factors: national composition of students; appropriate staff composition; selection of textbooks and manuals.

V. Naumenko attributed a course of native land history, native literature, geography and ethnography, as well as acquiring scientific knowledge of the Ukrainian language, to the subjects to be introduced at high school [27]. The teacher emphasized that the necessity of introducing along with the subject of the native land geography also the course of ethnography is explained by pedagogical tasks.

Filling the content of education with Ukrainian subjects required changes to the curriculum in order not to load students with an excessive amount of information. To solve this problem, V. Naumenko offered to remove from the programs of history, literature and geography all that was taught only to satisfy the requirements of the tsarist regime. According to the teacher, the program hours were released and could be filled with Ukrainian subjects.

According to V. Naumenko, reforming the content of education involved changing the requirements for the teacher, his knowledge and working methods. "If we are to start a school reorganization, - he noted, - it is not so much a question of how a school can be reorganized, but a matter of how well the teaching staff is prepared" [27]. Teacher training was an urgent need. The teacher considered that the success of the initiative depends on it. "Otherwise, he said, - it cannot be". In order to be sufficiently prepared for pedagogical activity in the national Ukrainian school, it is necessary for the teaching staff to be at the highest level of knowledge of their mother tongue, not only practically but also theoretically, and also to be familiar with the main scientific subjects closely related to the national type, like: literature, history, geography, ethnography" [26].

V. Naumenko paid much attention to the organization of pedagogical courses for teachers. To expedite this work, he suggested " ... to divide the courses into the district ones so that each district could arrange monthly courses for the teachers of their own districts, and to devote all their efforts to teaching the Ukrainian language ..." [27].

With the aim of territorial extension of the courses for the training of teachers for the school Ukrainization, V. Naumenko suggested several rational steps: shift work of the heads of the district courses; urgent preparation of distruct courses methodologists for 70-hour lectures that could be taught in provinces.

He personally develops a teacher training program for the Ukrainian school. For example, in teaching literacy V. Naumenko considered it necessary to familiarize the students with the methods of explanatory reading, the peculiarities of Ukrainian writing and to offer reading materials.

The Methodist advised to devote the second part of the courses to teaching arithmetic in the Ukrainian language. In addition, V. Naumenko considered it necessary to teach a brief course on the history of Ukraine, on the history of Ukrainian literature, especially in the 19th century, further on the geography of Ukrainian and the Ukrainian language.

The Methodist emphasized the importance of the course leader personality. "The trust and the authority acknowledgement of the courses teacher is of utmost im- 
portance. If there is no such trust and authority, then the work becomes a formality, a toy", V. Naumenko warned. In the case of selection of methodological courses leaders V. Naumenko paid great attention to the "conscious Ukrainian intellectuals", who was interested in the effectiveness of the process of Ukrainization of education [26].

\section{Conclusions}

Thus, V. Naumenko, who was entrusted with the case of Ukrainization of the schools of the Kyiv educational district, determined the conditions for reforming the school and the content of education, as well as the ways of introducing theoretical foundations into the public school practice. According to the teacher, solving these tasks required special training of teaching staff, support of the progressive Ukrainian intelligentsia, and conscious attitude of the people to the reorganization of education, taking into account the territorial location of the educational institution in the process of Ukrainization.

Active public activity, scientific and educational work, development of appropriate programs and creation of textbooks for public schools - each of these activities was a kind of stone in creating the foundation for Ukrainian education. V. Naumenko's role as one of the founders of national education was both in the scientific and theoretical substantiation of the foundations of Ukrainian schooling and in the practical implementation of educational ideas in the life of the Ukrainian population.

The study does not cover all aspects of the problem. Linguistic aspects of V. Naumenko's legacy need further study and generalization. Also promising are studies of the scientist's contribution to the development of archival and library affairs, a comparative analysis of pedagogical ideas of V. Naumenko and his socio-cultural activities with other representatives of domestic and foreign progressive intelligentsia.

\section{References}

[1] L. Berezivska, Osvitno-vykhovna diialnist kyivskykh prosvitnytskykh tovarystv (druha polovyna XIX poch. XX st.) (Educational activity of Kyiv educational societies (second half of the XIX - beginning of the XX century)) (Molod, Kyiv, 1999)

[2] L. Vovk, Hromadsko-pedahohichne spodvyzhnytstvo $v$ Ukraini (etapy $i$ osoblyvosti) Social and pedagogical community in Ukraine (stages and features) (Mizhnar. fin. ahentsiia, Kyiv, 1997)

[3] I. Zaichenko, Historical and Pedagogical Almanac 2 (2006)

[4] I. Likarchuk, Ministry osvity Ukrainy (Ministers of Education of Ukraine), Vol. 1 (Eshke O.M., Kyiv, 2002)

[5] I. Likarchuk, Ministry osvity Ukrainy (Ministers of Education of Ukraine), Vol. 2 (Eshke O.M., Kyiv, 2010)

[6] N. Pobirchenko, Pedahohichna i prosvitnytska diialnist ukrainskykh hromad u II polovyni XIX - na pochatku XX stolittia (Issues of national education and upbringing in the activities of Ukrainian Communities (the second half of the XIX - beginning of the XX century) (Naukovyi svit, Kyiv, 2000)

[7] I. Nadiezhdina, Ph.D. thesis, Ternopil National Pedagogical University named after Volodymyr Hnatyuk, Ternopil, Ukraine (2019)

[8] V. Naumenko, Literaturnyi russkii yazyk $v$ shkolakh tekh mestnostei, v kotorykh on ne yavlyaetsya rodnym yazykom (Literary Russian in schools of those places where it is not a native language) (Institute of Manuscripts of the Vernadskyi National Library of Ukraine, Kyiv, n.d.), fund 1, 634/1300, p. 7

[9] V. Naumenko, Otechestvennyi yazyk kak predmet gimnazicheskogo kursa. Rech', chitannaya na torzhestvennom akte Kievskoi 2-i gimnazii 30 sentyabrya 1881 goda (Mother tongue as a subject of a gymnasium course. Speech at the solemn act of the 2 nd Kiev gymnasium on September 30, 1881) (Kyiv, 1881)

[10] V. Naumenko, Kievskaya starina 64(3) (1899)

[11] V. Naumenko, Kievskaya starina 64(3) (1899)

[12] V. Naumenko, Kievskaya starina 92(2) (1906)

[13] Delo o deyatel'nosti Kievskogo obshchestva sodeistviya nachal'nomu obrazovaniyu (Case over the activities of Kyiv Society for the Promotion of Primary Education) (Central State Historical Archive of Ukraine, Kyiv, 1904), fund 442, 657/203, pp. 17,18

[14] V. Naumenko, Lyst do Ye. Chykalenka (Letter to Ye. Chykalenko) (Institute of Manuscripts of the Vernadskyi National Library of Ukraine, Kyiv, 1904), fund 1, 35636, p. 2

[15] O chlenakh pravleniya "Obshchestva sodeistviya srednemu obrazovaniyu $v$ g. Kieve” Naumenko V.P., Shenfel'de S.V. Iz spiskov prosvetitel'skikh obshchestv $v g$. Kieve, sostavlennykh $v$ kantselyarii Kievskogo gubernatora (About the board members of the "Kyiv society for the promotion of secondary education" Naumenko V.P., Shenfelde S.V. From the lists of educational societies in Kiev compiled in the chancellery of the Kyiv Governor) (Central State Historical Archive of Ukraine, Kyiv, 1908), fund 275, 1727, pp. 8-13

[16] Delo o zakrytii Kievskogo obshchestva gramotnosti, rasprostranyavshego $v$ Yugo-Zapadnom krae nelegal'nuyu literaturu. Imeyutsya svedeniya o deyatel'nosti Umanskoi komissii Kievskogo obshchestva gramotnosti (1907-1909) (Case of closing the Kyiv Literacy Society, which distributed illegal literature in the Southwest territory. There is an information about the activities of Uman Commission of Kyiv Literacy Society (1907-1909)) (Central State Historical Archive of Ukraine, Kyiv, 1909), fund 442, 857/146

[17] Ustav, instruktsii i polozheniya Kievskogo obshchestva gramotnosti (Charter, instructions and provisions of Kyiv Literacy Society) (Central State Historical Archive of Ukraine, Kyiv, 1899), fund 318, $1 / 1532$ 
[18] Otchet o deyatel'nosti Kievskogo obshchestva gramotnosti (Report on the activities of Kyiv Literacy Society) (Central State Historical Archive of Ukraine, Kyiv, 1901), fund 442, 655/35

[19] Ministry of Education, Tsirkulyar o popolnenii bibliotek srednikh uchebnykh zavedenii tol'ko knigami, odobrennymi Ministerstvom narodnogo prosveshcheniya i dukhovnym vedomstvom (Circular on replenishing the libraries of secondary schools only with books approved by the Ministry of Education and the Department of Religious Affairs) (Central State Historical Archive of Ukraine, Kyiv, 1904), fund 707, 192/54

[20] Y. Chykalenko, Spohady (1861-1907) (Memoirs (1861-1907)), Vol. 2 (Dilo, Lviv, 1999)

[21] S. Siropolko, Istoriia osvity v Ukraini (History of Education in Ukraine) (Naukova Dumka, Kyiv, 2001)

[22] Ustav Obshchestva Prosvita v Kieve (Charter of the Society of Education in Kiev) (Central State Historical Archive of Ukraine, Kyiv, 1906), fund 275, $1 / 1889$

[23] Dokladnaya zapiska Kievskogo okhrannogo otdeleniya $v$ Departament politsii ob ukrainskom i natsional'nom dvizhenii (o deyatel'nosti obshchestva
"Prosvita”) (Internal report of Kyiv Security Department to the Police Department on the Ukrainian and national movement (on the activities of the Prosvita Society) (Central State Historical Archive of Ukraine, Kyiv, 1910), fund 275, 1/2198

[24] Pro pedahohichnu diialnist V.P. Naumenka na posadi dyrektora Kyivskoho pryvatnoi cholovichoi himnazii (1905-1911) (On the pedagogical activity of V.P. Naumenko as principal of Kyiv Private Boy's Gymnasium (1905-1911)) (Central State Historical Archive of Ukraine, Kyiv, 1911), fund 442, 858/125

[25] S. Rusova, Dopovidna zapyska pro znachennia "Prosvity" dlia kulturnoho rozvytku narodu (On the importance of Prosvita Society for the cultural development of people Internal Report) (Central State Archive of the Highest Authorities and Administration of Ukraine, Kyiv, n.d.), fund 2201, 2/381

[26] V. Naumenko, Kievskaya mysl' 81 (1917)

[27] Delo o vvedenii prepodavaniya predmetov v uchebnykh zavedeniyakh Okruga na ukrainskom yazyke (Case over the introduction of teaching subjects in the District educational institutions in Ukrainian) (Central State Historical Archive of Ukraine, Kyiv, 1917), fund 707, 299/325 